\title{
STUDIES OF THE ANTIDIURESIS OF QUIET STANDING: THE IMPORTANCE OF CHANGES IN PLASMA VOLUME AND GLOMERULAR FILTRATION RATE ${ }^{1}$
}

\author{
By FRANKLIN H. EPSTEIN,2 ALLAN V. N. GOODYER, ${ }^{3}$ F. DOUGLAS LAWRASON, ${ }^{4}$ \\ AND ARNOLD S. RELMAN 5 \\ (From the Evans Memorial, Massachusetts Memorial Hospitals, the Department of Medicine, \\ Boston University School of Medicine, Boston; and the Department of Internal \\ Medicine, Yale University School of Medicine, New Haven)
}

(Submitted for publication August 21, 1950; accepted, October 17, 1950)

\section{INTRODUCTION}

It has long been known that when a man stands motionless, urine flow (1-13) and the excretion of chloride $(2,3,5,7,11)$ and of sodium $(5,13)$ decrease markedly. Simultaneously, the plasma contracts in volume and increases in concentration $(8,10,14-17)$, while the blood flow through the kidneys $(9,10,18,19)$ and other abdominal viscera (20) diminishes, and the rate of glomerular filtration of plasma and its contained sodium is reduced $(6,9,10,13,18,21)$.

There is some evidence that release of the posterior pituitary antidiuretic hormone may be responsible for the retention of water (11) but the mechanism of the retention of sodium and the stimulus or stimuli initiating it remain obscure. Some renal physiologists would place greatest emphasis on the reduction in glomerular filtration rate which occurs during standing, and the resulting decreased load of sodium presented to the tubules $(5,22,23)$. It is not likely that an increase in the renal venous pressure $(24,25)$ plays an important role in the antidiuresis of quiet standing, because when a subject is tilted from the supine to the erect position, pressure in the inferior vena cava at the level of the kidneys does not rise to the level reported by Blake and associates (25) to cause a reduction in the urine flow, and the renal arterio-venous pressure gradient does not change materially (26).

\footnotetext{
1 Presented in part before the National Meeting of the American Federation for Clinical Research, May, 1950. 2 Captain, M. C., U. S. A.

3 Scholar in Medical Science, The John and Mary $\mathbf{R}$. Markle Foundation.

4 During tenure as James Hudson Brown Research Fellow, Yale University School of Medicine.

5 During tenure as Fellow in the Medical Sciences, National Research Council. Present address: Evans Memorial, Boston.
}

It has also been suggested that the reduction of total blood volume initiates a chain of events which culminates in decreased excretion of sodium (2729). This might be accomplished through changes in glomerular filtration and/or tubular reabsorption of sodium. Some workers believe that this mechanism may operate in such diverse situations as hemorrhage, hypoproteinemic edema and congestive heart failure, as well as in quiet standing $(28,30)$.

The present studies were undertaken to investigate the relationship of changes in total plasma volume and glomerular filtration rate to the renal excretion of sodium during quiet standing.

\section{METHODS}

All subjects were healthy young men, presumably able to empty their bladders without catheterization. Relatively high urine flows and long periods minimized any errors in collection. A fairly constant rate of excretion of sodium was achieved by the ingestion of $200 \mathrm{ml}$. of hypotonic $(0.2 \%)$ saline solution per hour for several hours (31), and by preliminary rest supine in bed for at least one hour, before observations were begun. Subjects continued to drink saline at the same rate during the experimental period. In five experiments (Nos. 1, $10,11,13,14)$ the glomerular filtration was estimated from the clearance of mannitol, using the single injection method with a falling plasma concentration (32). Previous observations had demonstrated that one could maintain a constant diuresis of salt and water for several hours under these conditions (33). In six cases (Nos. 4-6, 8, 9, 15) a constant infusion of mannitol was used, and in the remaining experiments a constant infusion of inulin. Renal plasma flow was calculated from the clearance of sodium para-aminohippurate administered as a constant infusion in normal saline. Mannitol in serum and urine was analyzed by the method of Smith (34), modified according to Elkinton (35). Inulin and para-aminohippurate were determined using methods described by Goldring and Chasis (36). Concentrations of sodium in serum and urine were measured with a flame photometer. Acute changes in plasma volume (PV) were calculated 
TABLE I

Changes in sodium excretion, plasma volume and renal function with quiet standing

\begin{tabular}{|c|c|c|c|c|c|c|c|c|c|c|c|c|}
\hline $\begin{array}{l}\text { Experi- } \\
\text { ment } \\
\text { no. and } \\
\text { subject }\end{array}$ & Period & $\begin{array}{c}\text { Dura- } \\
\text { tion }\end{array}$ & $\begin{array}{l}\text { Urine } \\
\text { flow }\end{array}$ & $\begin{array}{l}\text { Sodium } \\
\text { excretion }\end{array}$ & $\begin{array}{l}\text { Mannitol } \\
\text { clearance }\end{array}$ & $\begin{array}{c}\text { Inulin } \\
\text { clearance }\end{array}$ & $\begin{array}{c}\text { Average } \\
\text { eerum } \\
\mathrm{Na}\end{array}$ & $\begin{array}{l}\text { Sodium } \\
\text { filtered }\end{array}$ & $\frac{\mathrm{E}^{*}}{\mathrm{~F}} \mathrm{Na}$ & $\begin{array}{l}\% \text { Change } \\
\text { in plamma } \\
\text { volume } \\
\text { from } \\
\text { control }\end{array}$ & $\begin{array}{c}\text { PAH } \\
\text { clearance }\end{array}$ & \begin{tabular}{|l} 
Mannitol \\
excreted
\end{tabular} \\
\hline ERP & $\begin{array}{l}\text { 1-supine } \\
\text { 2-standing } \\
\text { 3-supine }\end{array}$ & $\begin{array}{c}\min . \\
67 \\
60 \\
61\end{array}$ & \begin{tabular}{|c} 
ml. $/$ min. \\
4.18 \\
1.97 \\
0.74
\end{tabular} & $\begin{array}{c}\text { mEq. } / \text { min. } \\
\text { per } 1.73 \text { m }^{2} \\
0.159 \\
0.0714 \\
0.0197\end{array}$ & $\begin{array}{c}\text { ml. } / \text { min. } \\
\text { per } 1.73 \text { m } \\
85.6 \\
76.0 \\
61.3\end{array}$ & 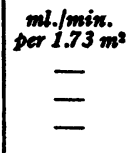 & \begin{tabular}{l|l}
$m E q . / L$ \\
136.5 \\
136.5 \\
136.5
\end{tabular} & \begin{tabular}{|c|} 
mEq. $/$ min \\
per $1.73 \mathrm{~m}^{2}$ \\
11.5 \\
10.21 \\
8.27
\end{tabular} & $\left|\begin{array}{l}0.014 \\
0.007 \\
0.002\end{array}\right|$ & $\begin{array}{r}0 \\
-13 \\
-4\end{array}$ & $\begin{array}{c}\text { ml./min. } \\
\text { per } 1.73 \mathrm{~m}^{2} \\
= \\
=\end{array}$ & $\begin{array}{l}\text { mM/min. } \\
0.43 \\
0.25 \\
0.14\end{array}$ \\
\hline$\stackrel{2}{2}$ & $\begin{array}{l}\text { 1-supine } \\
\text { 2-supine } \\
\text { 3-standing } \\
\text { 4-supine }\end{array}$ & $\begin{array}{l}30 \\
32 \\
25 \\
38\end{array}$ & $\begin{array}{l}8.1 \\
5.0 \\
1.6 \\
2.4\end{array}$ & $\begin{array}{l}0.266 \\
0.305 \\
0.218 \\
0.252\end{array}$ & $\bar{z}$ & $\begin{array}{r}108.3 \\
99.4 \\
85.0 \\
86.0\end{array}$ & $\begin{array}{l}144.0 \\
144.5 \\
145.0 \\
144.5\end{array}$ & $\begin{array}{l}15.5 \\
14.3 \\
12.2 \\
12.3\end{array}$ & $\left|\begin{array}{l}0.017 \\
0.021 \\
0.018 \\
0.020\end{array}\right|$ & $\begin{array}{r}0 \\
-6 \\
-10 \\
-8\end{array}$ & $\begin{array}{l}\mathbf{5 9 9} \\
\mathbf{5 5 6} \\
\mathbf{5 2 6} \\
\mathbf{5 8 9}\end{array}$ & $\bar{z}$ \\
\hline$\stackrel{3}{A S R}$ & $\begin{array}{l}\text { 1-supine } \\
\text { 2-supine } \\
\text { 3-standing } \\
\text { 4-standing } \\
\text { 5-supine } \\
\text { 6-supine }\end{array}$ & $\begin{array}{l}30 \\
30 \\
30 \\
30 \\
30 \\
31\end{array}$ & $\begin{array}{l}3.90 \\
3.93 \\
1.55 \\
0.57 \\
0.77 \\
1.16\end{array}$ & $\begin{array}{l}0.181 \\
0.155 \\
0.096 \\
0.073 \\
0.081 \\
0.090\end{array}$ & $\begin{array}{l}\bar{z} \\
\bar{z}\end{array}$ & $\begin{array}{l}\bar{z} \\
\bar{z}\end{array}$ & $\begin{array}{l}\bar{z} \\
\bar{z}\end{array}$ & $\begin{array}{l}\bar{z} \\
\bar{z}\end{array}$ & $\begin{array}{l}\bar{z} \\
\bar{z}\end{array}$ & $\begin{array}{l}-0 \\
-7 \\
-7\end{array}$ & $\begin{array}{l}722 \\
585 \\
526 \\
548 \\
743 \\
787\end{array}$ & $\begin{array}{l}\bar{z} \\
\bar{z}\end{array}$ \\
\hline
\end{tabular}

* Sodium excreted

Sodium filtered

from changes in the hemoglobin ( $\mathrm{Hgb})$ and hematocrit (Hct) of venous blood drawn without stasis, using formula :

$$
\frac{\mathrm{PV}_{2}}{\mathrm{PV}_{1}}=\frac{\mathrm{Hgb}_{1}}{\mathrm{Hgb}_{2}} \times \frac{1-\mathrm{Hct}_{\mathrm{F}}}{1-\mathrm{Hct}_{1}},
$$

where the numbers in subscript indicate the values at the beginning and the end of a given period, respectively. Samples of blood for analysis were drawn at the beginning and at the end of each clearance period. The rate of filtration of sodium was calculated as the product of the average concentration of serum sodium and glomerular filtration rate, corrected for an assumed serum water concentration of .93 and a Donnan factor for sodium of 0.95 . The fraction of filtered sodium rejected by the tubules and appearing in the urine was calculated as the fraction:

$$
\frac{\mathrm{Na} \text { excreted }}{\text { Na filtered }},(\mathrm{E} / \mathrm{F} \mathrm{Na}) \text {. }
$$

\section{RESULTS}

\section{Quiet Standing Alone (Table I) :}

In three subjects the renal effects of standing quietly for 25 to 60 minutes were quite typical of

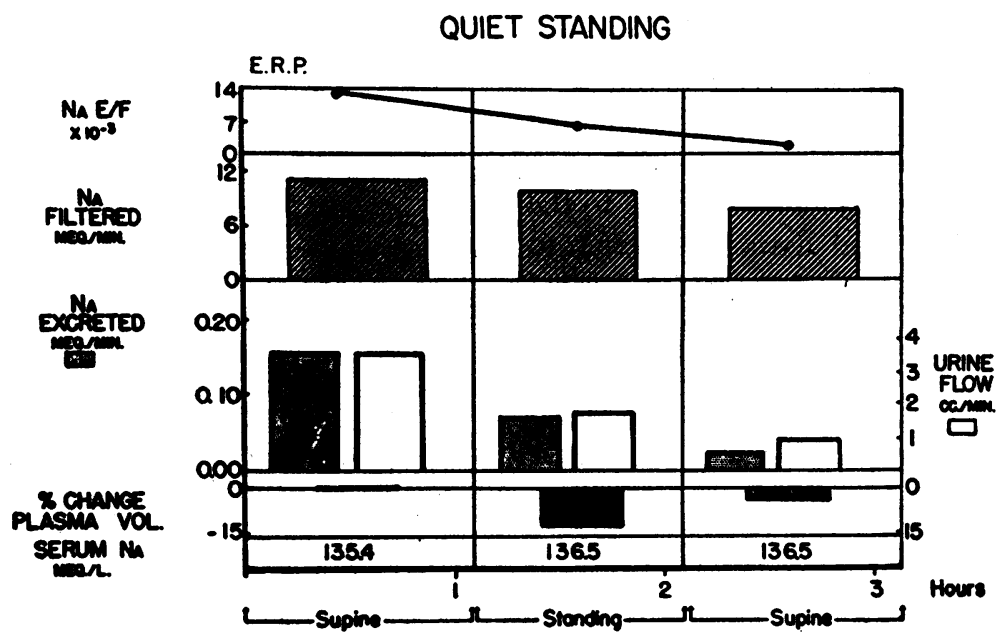

Fic. 1. Efrect of One Hour of Quiet Standing

Note prolonged antidiuresis and the reduction in sodium excretion, associated with a significant contraction of plasma volume. 
TABLE II

Effect of infusions of serum albumin during quiet standing

\begin{tabular}{|c|c|c|c|c|c|c|c|c|c|c|c|c|}
\hline $\begin{array}{c}\text { Experi- } \\
\text { ment } \\
\text { no. and } \\
\text { subject }\end{array}$ & Period & $\begin{array}{l}\text { Dura- } \\
\text { tion }\end{array}$ & $\begin{array}{l}\text { Urine } \\
\text { flow }\end{array}$ & $\begin{array}{c}\text { Sodium } \\
\text { excretion }\end{array}$ & $\begin{array}{l}\text { Mannitol } \\
\text { clearance }\end{array}$ & $\begin{array}{c}\text { Inulin } \\
\text { clearance }\end{array}$ & $\begin{array}{c}\text { Average } \\
\text { serum } \\
\mathrm{Na}\end{array}$ & $\begin{array}{l}\text { Sodium } \\
\text { filtered }\end{array}$ & $\frac{\mathrm{E}^{*}}{\mathrm{~F}} \mathrm{Na}$ & $\begin{array}{c}\text { \% Change } \\
\text { in plasme } \\
\text { volume } \\
\text { from } \\
\text { control }\end{array}$ & $\begin{array}{c}\text { PAH } \\
\text { clearance }\end{array}$ & $\begin{array}{l}\text { Mannitol } \\
\text { excreted }\end{array}$ \\
\hline$\stackrel{4}{\mathrm{GG}}$ & $\begin{array}{l}\text { 1-supine } \\
\text { 2-standing } \\
300 \mathrm{ml} .25 \% \\
\text { albumin in } \\
34 \text { min. } \\
\text { 3-supine }\end{array}$ & $\begin{array}{c}\min . \\
57 \\
49\end{array}$ & $\begin{array}{c}\text { ml. } . \min . \\
9.39 \\
4.59\end{array}$ & $\begin{array}{c}\operatorname{mEq} . / \min \\
\text { per } 1.73 \mathrm{~m}^{2} \\
0.150 \\
0.103 \\
\\
\\
\\
0.043\end{array}$ & $\begin{array}{c}\text { ml./min. } \\
\text { per } 1.73 \mathrm{~m}^{2} \\
86.5 \\
79.6\end{array}$ & $\begin{array}{c}\text { ml./min. } \\
\text { per } 1.73 \mathrm{~m}^{2} \\
- \\
-\end{array}$ & $\begin{array}{c}m E q . / L \\
132.5 \\
134.7 \\
135.9\end{array}$ & $\begin{array}{c}m E q . / m i n \\
\text { per } 1.73 m^{2} \\
11.4 \\
10.6\end{array}$ & $\begin{array}{l}0.013 \\
0.010 \\
0.004\end{array}$ & $\begin{array}{r}0 \\
+6 \\
+26\end{array}$ & \begin{tabular}{|c|} 
ml. $/ m^{2} i x$. \\
per $1.73 \mathrm{~m}^{2}$ \\
524 \\
474
\end{tabular} & $\begin{array}{c}m M / m i n . \\
0.52 \\
0.43 \\
\\
\\
0.37\end{array}$ \\
\hline$\stackrel{5}{I T}$ & $\begin{array}{l}\text { 1-supine } \\
\text { 2-standing } \\
750 \mathrm{ml} .4 \% \\
\text { albumin in } \\
34 \text { min. } \\
\text { 3-standing }\end{array}$ & $\begin{array}{l}33 \\
44\end{array}$ & $\begin{array}{l}5.15 \\
4.54\end{array}$ & $\begin{array}{l}0.223 \\
0.194\end{array}$ & $\begin{array}{l}79.0 \\
72.0\end{array}$ & - & $\begin{array}{l}141.2 \\
139.6 \\
138.9\end{array}$ & $\begin{array}{l}11.0 \\
10.0\end{array}$ & $\begin{array}{l}0.020 \\
0.019 \\
0.012\end{array}$ & $\begin{array}{r}0 \\
+4\end{array}$ & $\begin{array}{l}498 \\
479\end{array}$ & $\begin{array}{l}0.53 \\
0.52\end{array}$ \\
\hline$\stackrel{6}{\text { ASR }}$ & $\begin{array}{l}\text { 1-supine } \\
\text { 2-supine } \\
\text { 3-standing } \\
750 \mathrm{ml} .4 \% \\
\text { albumin in } \\
30 \text { min. } \\
\text { 4-standing } \\
5 \text {-supine }\end{array}$ & $\begin{array}{l}35 \\
33 \\
37\end{array}$ & $\begin{array}{l}3.51 \\
5.24 \\
3.51\end{array}$ & $\begin{array}{l}0.180 \\
0.283 \\
0.208\end{array}$ & $\begin{array}{l}92.0 \\
97.0 \\
82.3\end{array}$ & Z & E & $\begin{array}{l}12.9 \dagger \\
13.6 \\
11.5\end{array}$ & $\begin{array}{l}0.014 \\
0.021 \\
0.018\end{array}$ & $\begin{array}{r}0 \\
0 \\
+\quad 3\end{array}$ & E & $\begin{array}{l}0.52 \\
0.56 \\
0.47\end{array}$ \\
\hline$\stackrel{7}{\text { FHE }}$ & $\begin{array}{l}\text { 1-supine } \\
\text { 2-supine } \\
\text { 3-supine } \\
4 \text {-standing } \\
750 \mathrm{ml} .4 \% \\
\text { albumin in } \\
35 \text { min. } \\
\text { 5-standing }\end{array}$ & $\begin{array}{l}25 \\
32 \\
30 \\
42\end{array}$ & $\begin{array}{l}7.40 \\
4.37 \\
5.33 \\
2.02\end{array}$ & $\begin{array}{l}0.451 \\
0.533 \\
0.500 \\
0.240\end{array}$ & E & $\begin{array}{l}96 \\
92 \\
90 \\
83\end{array}$ & $\begin{array}{l}145.8 \\
145.0 \\
144.5 \\
145.0 \\
\\
\\
144.8\end{array}$ & $\begin{array}{l}13.9 \\
13.2 \\
12.9 \\
11.9\end{array}$ & $\begin{array}{l}0.032 \\
0.040 \\
0.039 \\
0.020 \\
\\
0.008\end{array}$ & $\begin{array}{r}0 \\
+4 \\
+\quad 6 \\
+7\end{array}$ & $\begin{array}{l}625 \\
642 \\
675 \\
578\end{array}$ & z \\
\hline
\end{tabular}

* Sodium excreted

Sodium filtered

† Serum concentration of $\mathrm{Na}$ assumed to be $140 \mathrm{mEq}$./L.

those described by others (Figure 1). Renal plasma flow, the filtration and excretion of water and sodium, and the tubular rejection of sodium $(\mathrm{E} / \mathrm{F} \mathrm{Na})$ all decreased. These changes lasted for some time after resumption of the supine position. Plasma volume decreased by 4 to $13 \%$, but [as previously reported for serum chloride and bicarbonate (14)] the concentration of serum sodium did not change significantly.

Quiet Standing with Albumin Infusion (Table II) :

To determine whether this sequence of events would be altered if the contraction of plasma volume were prevented, four subjects were given infusions of salt-poor human serum albumin ${ }^{6}$ when they stood up. In three experiments, $750 \mathrm{ml}$. of

- Serum albumin used in this study was prepared by the American Red Cross from blood of volunteer donors. The conclusions are those of the authors and do not isosmotic albumin ( $4 \%$ solution in normal saline) were infused, while in one case, $300 \mathrm{ml}$. of a $25 \%$ solution were injected. The infusions were given over a period of 30 to 35 minutes. A typical result is shown in Figure 2. Although in all cases total plasma volume increased slightly, in no instance was the antidiuresis of salt and water, which ordinarily accompanies quiet standing, prevented; and in every case a fall in the glomerular filtration of sodium and in $\mathrm{E} / \mathrm{F} \mathrm{Na}$ occurred. In experiment 7 (Figure 2), the excretion of sodium continued to decline during the last period despite an increase above control levels in both plasma volume and filtered sodium. Changes in renal plasma flow tended to parallel changes in the rate of glomerular filtration.

necessarily reflect the policy of the National Blood Program of the American Red Cross. 


\section{QUIET STANDING WITH 750cc. 4\% ALBUMIN}

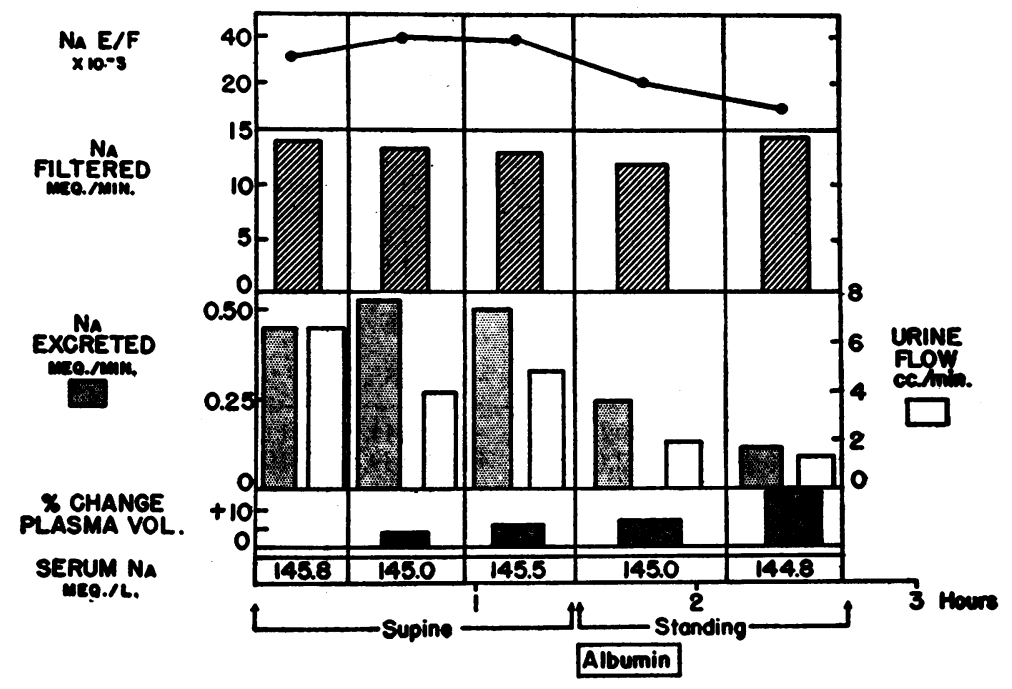

FIG. 2

Albumin infusion prevented the expected contraction of plasma volume during the period of quiet standing, but did not prevent the usual antidiuresis. Note that excretion of sodium and water continued to fall in the last period, although the rate of sodium filtration increased.

Effects of Infusions of Hypertonic Saline (Tables III and IV):

It is well known that the sodium diuresis following infusions of hypertonic saline is accompanied by an increase in the concentration of sodium in

the serum and expansion of the volume of the plasma and extracellular fluid. In two experiments (Table III), infusions of hypertonic saline $(6 \%)$ given to recumbent subjects sharply augmented the excretion of sodium, with (No. 9) or

TABLE III

Effect of rapid infusions of hypertonic sodium chloride in supine subjects

\begin{tabular}{|c|c|c|c|c|c|c|c|c|c|c|c|c|}
\hline $\begin{array}{c}\text { Experi- } \\
\text { ment } \\
\text { no. and } \\
\text { subject }\end{array}$ & Period & $\begin{array}{c}\text { Dura- } \\
\text { tion }\end{array}$ & $\begin{array}{l}\text { Urine } \\
\text { flow }\end{array}$ & $\begin{array}{c}\text { Sodium } \\
\text { excretion }\end{array}$ & $\begin{array}{l}\text { Mannitol } \\
\text { clearance }\end{array}$ & $\begin{array}{c}\text { Inulin } \\
\text { clearance }\end{array}$ & $\begin{array}{l}\text { Average } \\
\text { serum } \\
\mathrm{Na}\end{array}$ & $\begin{array}{l}\text { Sodium } \\
\text { filtered }\end{array}$ & $\frac{\mathrm{E}^{*}}{\mathrm{~F}} \mathrm{Na}$ & $\begin{array}{c}\% \text { Change } \\
\text { in plasma } \\
\text { volume } \\
\text { from } \\
\text { control }\end{array}$ & $\begin{array}{c}\text { PAH } \\
\text { clearance }\end{array}$ & $\begin{array}{l}\text { Mannitol } \\
\text { excreted }\end{array}$ \\
\hline$\stackrel{8}{\mathrm{McG}}$ & $\begin{array}{l}\text { 1-supine } \\
\text { 2-supine } \\
\text { 3-supine } \\
400 \mathrm{ml} .6 \% \\
\text { saline in } \\
23 \mathrm{~min} \text {. } \\
\text { 4-supine }\end{array}$ & $\begin{array}{c}\min . \\
39 \\
62 \\
47\end{array}$ & $\begin{array}{c}\text { ml./min. } \\
7.3 \\
9.2 \\
6.6\end{array}$ & $\begin{array}{c}\text { mEq.1min. } \\
\text { per } 1.73 \text { m }^{2} \\
0.224 \\
0.282 \\
0.870\end{array}$ & \begin{tabular}{|c|} 
ml. $/ \min ^{\text {per }} 1.73 \mathrm{~m}^{2}$ \\
119 \\
129 \\
120
\end{tabular} & $\begin{array}{c}\text { ml. } / \text { min. } \\
\text { per } 1.73 \mathrm{~m}^{2} \\
- \\
-\end{array}$ & $\begin{array}{c}m E q . / L \\
132.0 \\
135.9 \\
141.6 \\
\\
\\
143.8\end{array}$ & \begin{tabular}{|c|}
$\operatorname{mEq} . / \min$ \\
per $1.73 \mathrm{~m}^{\mathrm{e}}$ \\
15.55 \\
17.35 \\
16.94 \\
\\
\\
16.80
\end{tabular} & $\begin{array}{l}0.014 \\
0.016 \\
0.051 \\
\\
0.066\end{array}$ & E & $\begin{array}{c}\text { ml. } / \text { min. } \\
\text { per } 1.73 \mathrm{~m}^{2} \\
485 \\
536 \\
444\end{array}$ & $\begin{array}{c}\text { mM/min } \\
0.62 \\
0.68 \\
0.62\end{array}$ \\
\hline$\stackrel{9}{\mathrm{BR}}$ & $\begin{array}{l}\text { 1-supine } \\
\text { 2-supine } \\
\text { 3-supine } \\
400 \mathrm{ml} .6 \% \\
\text { saline in } \\
39 \text { min. } \\
\text { 4-supine }\end{array}$ & $\begin{array}{l}40 \\
39 \\
52 \\
\\
\\
34\end{array}$ & $\begin{array}{r}7.13 \\
10.40 \\
3.75 \\
\\
3.92\end{array}$ & $\begin{array}{l}0.135 \\
0.125 \\
0.287 \\
\\
\\
0.520\end{array}$ & $\begin{array}{l}120 \\
107 \\
116\end{array}$ & E & $\begin{array}{l}131.7 \\
133.5 \\
139.0 \\
\\
141.7\end{array}$ & $\begin{array}{l}15.65 \\
14.14 \\
15.95 \\
\\
\\
17.95\end{array}$ & $\begin{array}{l}0.009 \\
0.009 \\
0.018 \\
\\
0.029\end{array}$ & E & $\begin{array}{l}636 \\
651 \\
725\end{array}$ & $\begin{array}{l}0.48 \\
0.43 \\
0.47\end{array}$ \\
\hline
\end{tabular}

* Sodium excreted.

Sodium filtered 
TABLE IV

Effect of infusions of hypertonic sodium chloride during quiet standing

\begin{tabular}{|c|c|c|c|c|c|c|c|c|c|c|c|c|}
\hline $\begin{array}{l}\text { Experi- } \\
\text { ment } \\
\text { no. and } \\
\text { subject }\end{array}$ & Period & $\underset{\text { tion }}{\text { Dura- }}$ & $\begin{array}{l}\text { Urine } \\
\text { flow }\end{array}$ & $\begin{array}{c}\text { Sodium } \\
\text { excretion }\end{array}$ & $\begin{array}{l}\text { Mannitol } \\
\text { clearance }\end{array}$ & $\begin{array}{c}\text { Inulin } \\
\text { clearance }\end{array}$ & $\begin{array}{l}\text { Average } \\
\text { serum } \\
\mathbf{N a}\end{array}$ & $\begin{array}{l}\text { Sodium } \\
\text { filtered }\end{array}$ & $\frac{\mathrm{E}^{*}}{\mathrm{~F}} \mathrm{Na}$ & $\begin{array}{c}\text { \% Change } \\
\text { in plasma } \\
\text { volume } \\
\text { from } \\
\text { control }\end{array}$ & $\begin{array}{c}\text { PAH } \\
\text { clearance }\end{array}$ & \begin{tabular}{|l} 
Mannitol \\
excreted
\end{tabular} \\
\hline $\begin{array}{c}10 \\
\text { ASR }\end{array}$ & \begin{tabular}{|l|} 
1-supine \\
2-standing \\
3-standing \\
$400 \mathrm{ml} .3 \%$ \\
saline in \\
30 min.
\end{tabular} & $\begin{array}{l}\min . \\
49 \\
55 \\
63\end{array}$ & $\begin{array}{c}\text { ml. } / \min . \\
3.27 \\
1.36 \\
0.75\end{array}$ & \begin{tabular}{|c|}
$\underset{\text { per }}{\operatorname{me} .7 \mathrm{~min}}$. \\
0.296 \\
0.053 \\
0.023
\end{tabular} & \begin{tabular}{|c|} 
ml. $/ \min _{\text {in }}$ \\
per $1.73 \mathrm{~m}^{2}$ \\
108.0 \\
70.6 \\
64.9
\end{tabular} & $\begin{array}{c}\text { ml. } / \min _{\text {pin }} 1.73 \mathrm{~m}^{2} \\
- \\
-\end{array}$ & $\begin{array}{c}m E q . / L \\
140.5 \\
136.5 \\
142.0\end{array}$ & 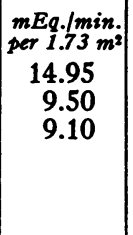 & $\left|\begin{array}{l}0.020 \\
0.006 \\
0.003\end{array}\right|$ & $\begin{array}{r}0 \\
-21 \\
+\quad 1\end{array}$ & $\begin{array}{c}\text { ml. } / \min . \\
\text { per } 1.73 \mathrm{~m}^{2} \\
- \\
-\end{array}$ & $\begin{array}{l}\text { mM/min. } \\
0.31 \\
0.18 \\
0.14\end{array}$ \\
\hline $\begin{array}{c}11 \\
\text { ERP }\end{array}$ & \begin{tabular}{|l|} 
1-supine \\
2-standing \\
$400 \mathrm{ml} .4 \%$ \\
saline in \\
$25 \mathrm{~min}$. \\
3-supine
\end{tabular} & $\begin{array}{l}50 \\
75\end{array}$ & $\begin{array}{l}4.00 \\
2.37\end{array}$ & $\begin{array}{l}0.438 \\
0.266 \\
\\
0.315\end{array}$ & $\begin{array}{l}88.3 \\
67.0\end{array}$ & 二 & $\begin{array}{l}137.2 \\
142.0 \\
\\
141.9\end{array}$ & $\begin{array}{r}12.1 \\
9.5\end{array}$ & $\begin{array}{l}0.036 \\
0.028 \\
\\
0.029\end{array}$ & - & $=$ & $\begin{array}{l}0.50 \\
0.23 \\
\\
0.13\end{array}$ \\
\hline $\begin{array}{c}12 \\
\text { FHE }\end{array}$ & \begin{tabular}{|l} 
1-supine \\
2-supine \\
3-standing \\
$400 \mathrm{ml} .6 \%$ \\
saline in \\
$35 \mathrm{~min}$. \\
4-standing
\end{tabular} & $\begin{array}{l}31 \\
39 \\
45\end{array}$ & $\begin{array}{l}4.68 \\
5.57 \\
2.04\end{array}$ & $\begin{array}{l}0.499 \\
0.554 \\
0.443 \\
\\
\\
0.439\end{array}$ & 二 & $\begin{array}{l}97.0 \\
94.0 \\
88.0\end{array}$ & $\begin{array}{l}146.0 \\
145.6 \\
149.7\end{array}$ & $\begin{array}{l}14.05 \\
13.58 \\
13.05\end{array}$ & $\begin{array}{l}0.035 \\
0.040 \\
0.034\end{array}$ & $\begin{array}{r}0 \\
-\begin{array}{r}1 \\
0\end{array}\end{array}$ & $\begin{array}{l}646 \\
638 \\
652\end{array}$ & $\bar{z}$ \\
\hline AVG & \begin{tabular}{|l|} 
1-supine \\
2-standing \\
$400 \mathrm{ml} .6 \%$ \\
saline in \\
$25 \mathrm{~min}$. \\
3-standing
\end{tabular} & $\begin{array}{l}48 \\
71\end{array}$ & $\begin{array}{l}5.10 \\
3.66\end{array}$ & $\begin{array}{l}0.666 \\
0.622 \\
\\
0.412\end{array}$ & $\begin{array}{l}98.0 \\
74.5\end{array}$ & 二 & $\begin{array}{l}136.5 \\
143.0\end{array}$ & $\begin{array}{l}13.3 \\
10.6\end{array}$ & $\begin{array}{l}0.050 \\
0.059\end{array}$ & - & 二 & $\begin{array}{l}0.28 \\
0.21 \\
0.20\end{array}$ \\
\hline $\begin{array}{c}14 \\
\text { FHE }\end{array}$ & \begin{tabular}{|l|} 
1-supine \\
2-standing \\
$400 \mathrm{ml} .6 \%$ \\
saline in \\
37 min. \\
3-supine \\
\end{tabular} & $\begin{array}{l}54 \\
63\end{array}$ & $\begin{array}{l}5.65 \\
4.92\end{array}$ & $\begin{array}{l}0.627 \\
0.743\end{array}$ & $\begin{array}{l}94.5 \\
86.3\end{array}$ & - & $\begin{array}{l}139.1 \\
146.5\end{array}$ & $\begin{array}{l}13.1 \\
12.6\end{array}$ & $\begin{array}{l}0.046 \\
0.059 \\
\\
0.067\end{array}$ & 二 & - & $\begin{array}{l}0.54 \\
0.32 \\
\\
0.24\end{array}$ \\
\hline $\begin{array}{c}15 \\
\mathrm{DM}\end{array}$ & \begin{tabular}{|l|} 
1-supine \\
2-supine \\
3-standing \\
$400 \mathrm{ml} .6 \%$ \\
saline in \\
26 min. \\
4-standing \\
\end{tabular} & $\begin{array}{l}40 \\
44 \\
41\end{array}$ & $\begin{array}{l}2.50 \\
3.07 \\
4.83\end{array}$ & $\begin{array}{l}0.210 \\
0.238 \\
0.468 \\
\\
\\
0.356\end{array}$ & $\begin{array}{r}100.0 \\
99.0 \\
92.0 \\
\\
\\
100.0\end{array}$ & $=$ & $\begin{array}{l}138.9 \\
137.6 \\
140.0\end{array}$ & $\begin{array}{l}13.80 \\
13.52 \\
12.80\end{array}$ & $\begin{array}{l}0.015 \\
0.017 \\
0.036\end{array}$ & $\begin{array}{r}0 \\
0 \\
+16 \\
\\
+11\end{array}$ & $\begin{array}{l}432 \\
522 \\
613 \\
\\
437\end{array}$ & $\begin{array}{l}0.62 \\
0.55 \\
0.49 \\
\\
\\
0.50\end{array}$ \\
\hline $\begin{array}{c}16 \\
\text { ASR }\end{array}$ & $\begin{array}{l}\text { 1-supine } \\
\text { 2-supine } \\
\text { 3-standing } \\
400 \mathrm{ml} .7 \frac{1}{2} \% \\
\text { saline in } \\
40 \text { min. } \\
4 \text {-standing }\end{array}$ & $\begin{array}{l}30 \\
31 \\
45\end{array}$ & $\begin{array}{l}3.80 \\
3.64 \\
3.04\end{array}$ & $\begin{array}{l}0.200 \\
0.259 \\
0.532\end{array}$ & 二 & $\begin{array}{r}100 . \\
89 . \\
105 .\end{array}$ & $\begin{array}{l}146.0 \\
145.5 \\
153.5\end{array}$ & $\begin{array}{l}16.60 \\
14.70 \\
18.30\end{array}$ & $\begin{array}{l}0.014 \\
0.020 \\
0.033\end{array}$ & $\begin{array}{l}\quad 0 \\
-2.5 \\
+18 \\
+17\end{array}$ & $\begin{array}{l}774 \\
697 \\
865\end{array}$ & $\bar{z}$ \\
\hline
\end{tabular}

* Sodium excreted

Sodium filtered

without (No. 8) increasing appreciably the glomerular filtration of sodium or the renal plasma flow. In seven other experiments (Table IV), therefore, the hypertonic saline was infused during a period of standing, in an attempt to observe how the plasma volume, the concentration of sodium in the serum, and the rate of glomerular filtration of sodium were related to the excretion of sodium when large loads of salt were administered to subjects assuming the erect posture. 


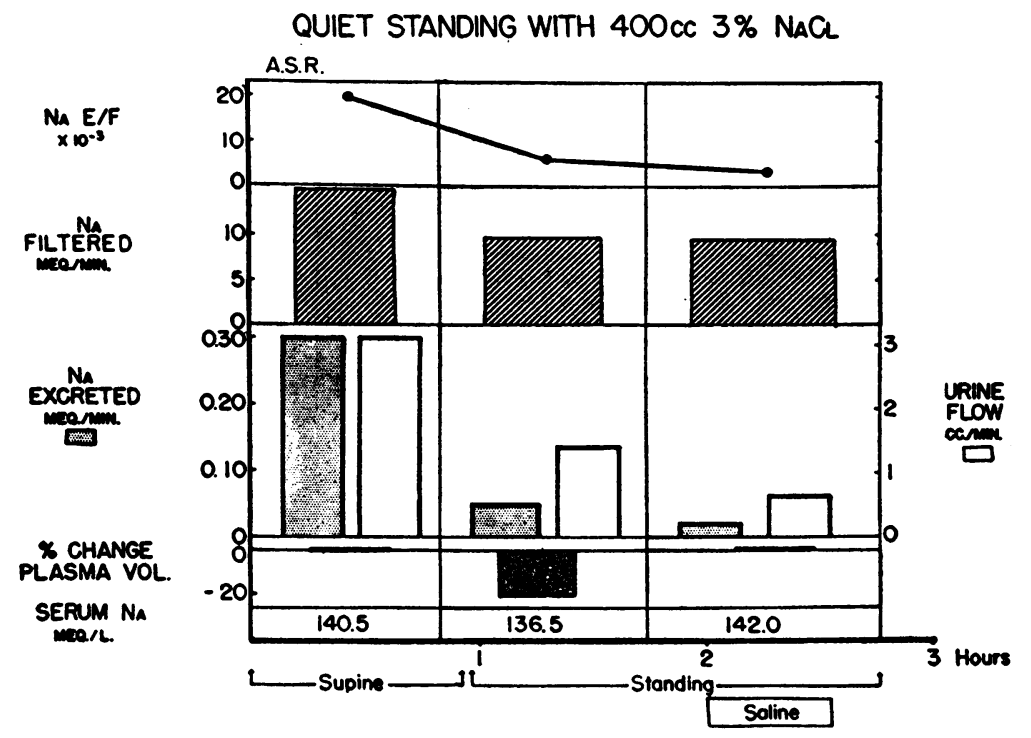

FIG. 3

The infusion restored the plasma volume to normal and prevented further significant change in sodium filtration. Despite this, urine flow and sodium excretion continued to diminish.

The rise in concentration of serum sodium was significant in all cases, but in only one was it adequate actually to increase the rate at which sodium was filtered during the period of standing. Plasma volume, calculated in some of these experiments, usually increased. The excretion of sodium declined in four instances and increased in three. As might be expected, the excretion of sodium seemed roughly proportional to the size of the salt load.

Subject ASR (No. 10, Table IV, and Figure 3) received 12 grams of salt as $400 \mathrm{ml}$. of $3 \%$ saline

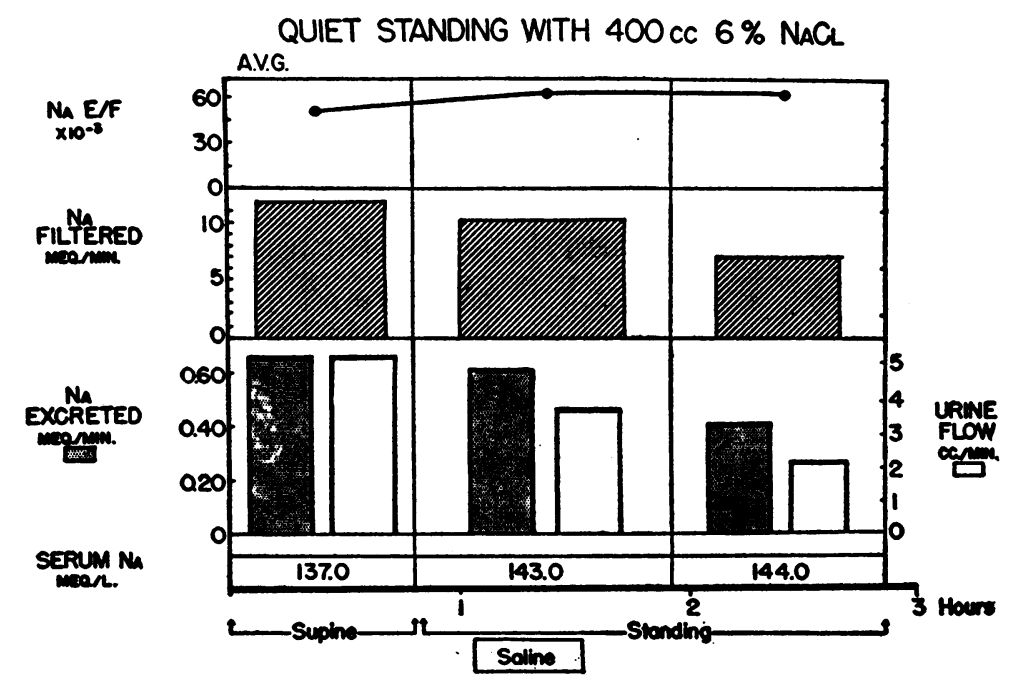

FIG. 4

The infusion did not prevent the reduction in urine flow and sodium filtration and excretion during the periods of quiet standing, but it did provoke the tubules to reject a larger fraction of the filtered sodium. 


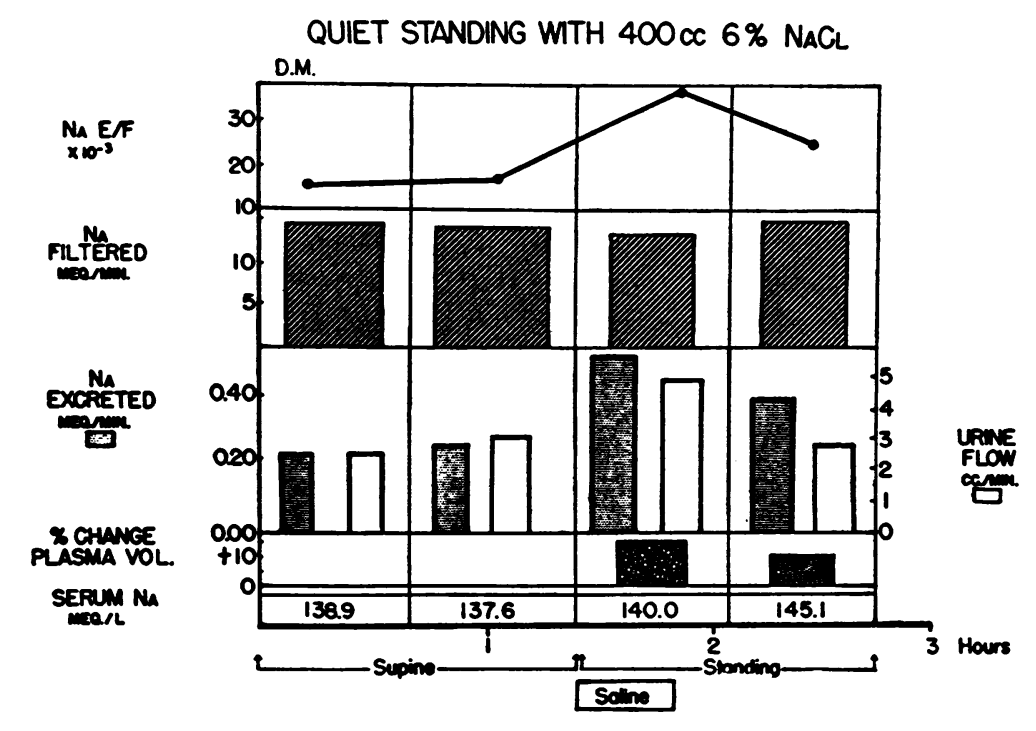

FIG. 5

Rapid administration of 24 grams of salt markedly increased plasma volume and sodium and water excretion during quiet standing, in the absence of significant changes in sodium filtration.

after a period of standing. This slightly increased the serum sodium and re-expanded the plasma volume to its control value. There was a further decline in the glomerular filtration of sodium of questionable significance. Despite this, sodium excretion decreased markedly, because the tubules reabsorbed a greater fraction of the filtered load of sodium presented to them. In an experiment in which $400 \mathrm{ml}$. of $4 \%$ saline were given (No. 11 , Table IV), essentially the same results were obtained.

In two experiments administration of $400 \mathrm{ml}$. of $6 \%$ saline did not prevent a decline in the glomerular filtration or in the excretion of sodium, but in AVG (No. 13, Table IV; Figure 4) it did cause the tubules to reject a slightly greater percentage of the filtered sodium.

In two other subjects (Nos. 14 and 15, Table IV; Figure 5), one of whom (No. 14) had ingested 24 grams of salt during the previous 24 hours, the same amount of $6 \%$ saline proved adequate completely to reverse the antidiuresis of quiet standing. Excretion of sodium actually rose considerably, together with an expansion of the plasma volume, and without any increase in the calculated rate of glomerular filtration of sodium.

Finally, in one case (No. 16), $400 \mathrm{ml}$. of $71 / 2 \%$ saline infused over 40 minutes not only increased the excretion of sodium during a period of quiet standing, but increased the glomerular filtration rate and renal plasma flow, as well as the plasma volume and the concentration of serum sodium.

\section{DISCUSSION}

These data confirm the earlier findings of others that a contraction of plasma volume, a decrease in renal clearances, and a diminished excretion of salt and water occur in the erect position. The fall in salt excretion during upright-tilting experiments, reported by Brun, Knudsen and Raaschou (9), was attributed by them to the fact that their subjects were in a state of pronounced negative chloride balance. This was not the case in the present studies, in which dilute saline was ingested for several hours preceding the test (31).

Infusions of $4 \%$ albumin do not influence the rate at which sodium is excreted by supine subjects $(37,38)$, although there is conflicting evidence concerning the effect of more concentrated solutions $(33,37,39-41)$. It would appear, therefore, from the experiments of Table II that the antidiuresis of quiet standing is not necessarily dependent upon a contraction of the total plasma volume, since excretion of salt and water diminished during standing, even when plasma volume was slightly expanded by rapid infusions of al- 
bumin. However, it must be emphasized that such infusions control only the-total volume of the circulating blood and do not necessarily alter its distribution during quiet standing. Blood pooled in certain peripheral areas may not contribute to the effectiveness of the circulation, and in this sense the "effective blood volume" (42) may be reduced even when the total blood volume remains unchanged. Standing erect decreases both the total and effective volumes of the circulation by increasing the capillary filtration and the pooling of blood in the limbs. When these disturbances are minimized by immersing the body in water up to the level of the heart or by applying pneumatic occluding cuffs to the legs, the antidiuresis of the erect posture is modified $(8,12)$. It would seem, therefore, that if the kidneys react to changes in some function of the volume of the circulating blood when a man stands erect, they must react more to changes in its effective distribution than in its total volume.

The view that the antidiuresis of quiet standing is mediated primarily through a change in renal hemodynamics was first advanced by Hooker, who invoked the narrowed pulse pressure in the renal artery as a cause for diminished urine flow $(4,43)$. White, Rosen, Fischer, and Wood (5) ascribed the increase in the excretion of water and electrolytes during recumbency mainly to an increase in glomerular filtration rate. On the other hand, $\mathrm{Ni}$ and Rehberg (6), using the clearance of exogenous creatinine as a measure of filtration rațe, came to the conclusion that postural changes in urine flow resulted from changes in both tubular reabsorption and glomerular filtration. In the present experiments, reductions in the urinary excretion of sodium during quiet standing were usually accompanied by significant alterations in both the filtration rate and the tubular rejection fraction of so$\operatorname{dium}(\mathrm{E} / \mathrm{F} \mathrm{Na})$. However, when infusions of albumin and hypertonic saline were given to subjects standing erect, a fall in sodium excretion was not always accompanied by a fall in the glomerular filtration of sodium (No. 7), nor did a small decrease in the filtration of sodium always result in diminished excretion of sodium (Nos. 14, 15).

These experiments appear to shed light on the nature of the renal response to loads of hypertonic saline, as well as to the upright posture. It has been suggested that the urinary excretion of sodium is normally regulated through fluctuations in its glomerular filtration $(22,23,44)$. Selkurt and Post (45) reported that when dogs are infused with hypertonic saline, the excretion of sodium varies as the filtered load, and Dean and McCance (46) concluded that during hypertonic saline infusions in human subjects, "changes in glomerular filtration must underlie, and in part determine, the observed changes in urine flow." It is therefore noteworthy that in experiments 8, 14 , and 15 , when $6 \%$ saline was infused, the excretion of sodium increased without a concomitant increase in filtered load (but not without an increase in plasma volume).

The use of mannitol in these experiments may be questioned on the grounds that since excreted mannitol may sweep salt into the urine $(22,44,47$, 48) sodium excretion might necessarily appear to be related to the excretion, and hence the filtration of mannitol. This consideration enhances the significance of such discordant changes in the filtration and excretion of sodium as were observed in experiments 8,14, and 15 . Nevertheless, even under the strenuous conditions of these experiments it was difficult to change greatly the excretion of sodium in a direction opposite to simultaneous changes in sodium filtration. This does not necessarily prove that excretion is dependent upon filtration, since they may both be related through a third controlling factor.

Except in cases where the changes are very large, the errors inherent in present measurements of glomerular filtration prevent any accurate apportionment of responsibility to tubules or glomeruli for alterations in sodium excretion. Each milliliter of glomerular filtrate contains approximately $0.14 \mathrm{mEq}$. of sodium. An unavoidable 5\% error in the estimation of glomerular filtration may therefore involve as much as $1 \mathrm{mEq} . / \mathrm{min}$. of sodium.

The renal response to salt loads is conditioned in part by the rise in concentration of sodium in the extracellular fluid. When infusions of hypertonic saline are given to thirsted subjects, the rate of sodium excretion rises, but drops sharply when the serum sodium is suddenly restored to normal by the ingestion of a large quantity of water (49). Some workers have concluded that when an infusion of hypertonic saline is given, 
"changes in sodium excretion are invoked by differences between extracellular and intracellular osmotic pressures" (50). The present studies show that even when the concentration of sodium in the serum rises significantly, it is sometimes possible to prevent or reverse the usual renal response by standing upright. A similar effect from abdominal compression has been reported recently (51).

The present data are consistent with the pluralistic view that alterations in both the composition and the effective distribution of the circulating plasma are important in initiating acute renal adjustments in sodium excretion. These adjustments may be accomplished by appropriate changes in the glomerular filtration or the tubular reabsorption of sodium, or both.

\section{CONCLUSIONS}

1. The antidiuretic reaction to standing does not require a contraction of the total plasma volume.

2. It is possible to reverse this reaction by administration of hypertonic saline without increasing the rate at which sodium is filtered; but in so doing, the plasma volume is expanded.

3. The renal response to sodium loads under these conditions is not dependent solely upon alterations in the glomerular filtration of sodium or in the concentration of sodium in the serum.

\section{REFERENCES}

1. Edel, P., "Cyklische" Albuminurie und neue Gesichtspunkte für die Bekämpfung von Albuminurien. München. med. Wchnschr., 1901, 48, 1833.

2. Linossier, G., and Lemoine, G. H., Influence de l'orthostatisme sur le fonctionnement du rein (I, II and III). Compt. rend. Soc. de biol., 1903, 55, 466, 469, 605.

3. Erlanger, J., and Hooker, D. R., The relation of blood pressure and pulse pressure to the secretion of urine and to the secretion of albumin in a case of so-called physiological albuminuria. Am. J. Physiol., 1903, 10, xvi.

4. Hooker, D. R., Hegeman, R. F., and Zartman, L. V., The relation of pulse pressure to the appearance of albumin in a case of orthostatic albuminuria. Am. J. Physiol., 1908, 23, xi.

5. White, H. L., Rosen, I. T., Fischer, S. S., and Wood, G. H., The influence of posture on renal activity. Am. J. Physiol., 1926, 78, 185.

6. Ni, T. G., and Rehberg, P. B., On the influence of posture on kidney function. J. Physiol., 1931, 71, 331.

7. Simpson, G. E., Changes in the composition of urine brought about by sleep and other factors. J. Biol. Chem., 1929, 84, 393.

8. Asmussen, E., Christensen, E. H., and Nielsen, M., The regulation of the circulation in different postures. Surgery, 1940, 8, 604.

9. Brun, C., Knudsen, E. O. E., and Raaschou, F., The influence of posture on the kidney function. I. The fall of diuresis in the erect posture. Acta med. Scandinav., 1945, 122, 315.

10. Brun, C., Knudsen, E. O. E., and Raaschou, F., The influence of posture on the kidney function. II. Glomerular dynamics in the passive erect posture. Acta med. Scandinav., 1945, 122, 332.

11. Brun, C., Knudsen, E. O. E., and Raaschou, F., On the cause of post-syncopal oliguria. Acta med. Scandinav., 1945, 122, 486.

12. Asmussen, E., Christensen, E. H., and Nielsen, M., III., Utber die Kreislaufinsuffizienz in stehender Stellung bei normalen arteriellen Druckund herabgesetztem Minutenvolumen. Skandinav. Arch. f. Physiol., 1939, 81, 214.

13. Kattus, A. A., Sinclair-Smith, B., Genest, J., and Newman, E. V., The effect of exercise on the renal mechanism of electrolyte excretion in normal subjects. Bull. Johns Hopkins Hosp., 1949, 84, 344.

14. Thompson, W. O., Thompson, P. K., and Dailey, M. $E$., The effect of posture upon the composition and the volume of the blood in man. J. Clin. Invest., 1928, 5, 573.

15. Waterfield, R. L., The effect of posture on the circulating blood volume. J. Physiol., 1931, 72, 110.

16. Krogh, A., Landis, E. M., and Turner, A. H., The movement of fluid through the human capillary wall in relation to venous pressure and to the colloid osmotic pressure of the blood. J. Clin. Invest., 1932, 11, 63.

17. Youmans, J. B., Wells, H. S., Donley, D., and Miller, D. G., The effect of posture (standing) on the serum protein concentration and colloid osmotic pressure of blood from the foot in relation to the formation of edema. J. Clin. Invest., 1934, 13, 447.

18. Smith, H. W., Lectures on the Kidney. University Extension Div., Univ. of Kansas, Lawrence, Kans., 1943.

19. Mayerson, H. S., The influence of posture on blood flow in the dog. Am. J. Physiol., 1940, 129, P421.

20. Culbertson, J. W., Wilkins, R. W., Ingelfinger, F. J., and Bradley, S. E., The effect of the upright posture upon hepatic blood flow in normal and hypertensive human subjects. J. Clin. Invest., 1947, 26, 1178.

21. White, H. L., and Rolf, D., Effects of exercise and some other influences on the renal circulation in man. Am. J. Physiol., 1948, 152, 505.

22. Wesson, L. G., Jr., Anslow, W. P., Jr., and Smith, 
H. W., The excretion of strong electrolytes. Bull. New York Acad. Med., 1948, 24, 586.

23. Selkurt, E. E., Hall, P. W., and Spencer, M. P., Influence of graded arterial pressure decrement on renal clearance of creatinine, $p$-aminohippurate and sodium. Am. J. Physiol., 1949, 159, 369.

24. Winton, F. R., Physical factors involved in activities of the mammalian kidney. Physiol. Rev., 1937, 17, 408.

25. Blake, W. D., Wégria, R., Keating, R. P., and Ward, $H$. P., Effect of increased renal venous pressure on renal function. Am. J. Physiol., 1949, 157, 1.

26. Wilkins, R. W., Personal communication.

27. Peters, J. P., Body Water; The Exchange of Fluids in Man. Charles C. Thomas, Springfield, Ill., 1935, p. 288.

28. Peters, J. P., The role of sodium in the production of edema. New England J. Med., 1948, 239, 353.

29. Peters, J. P., The significance of serum sodium. McGill M. J., 1949, 18, 130.

30. Borst, J. G. G., The cause of hyperchloremia and hyperazotemia in patients with recurrent massive hemorrhage from peptic ulcer. Acta med. Scandinav., 1938, 97, 68.

31. Wolf, A. V., The retention and excretion of continuously administered salt solutions. Am. J. Physiol., 1945, 143, 572.

32. Newman, E. V., Bordley, J., III, and Winternitz, J., The inter-relationships of glomerular filtration rate (mannitol clearance), extracellular fluid volume, surface area of the body, and plasma concentration of mannitol; a definition of extracellular fluid clearance determined by fcllowing plasma concentration after a single injection of mannitol. Bull. Johns Hopkins Hosp., 1944, 75, 253.

33. Goodyer, A. V. N., Peterson, E. R., and Relman, A. S., Some effects of albumin infusions on renal function and electrolyte excretion in normal man. J. Applied Physiol., 1949, 1, 671.

34. Smith, W. W., Finkelstein, N., and Smith, H. W., Renal excretion of hexitols (sorbitol, mannitol and dulcitol) and their derivatives (sorbitan, isomannide, and sorbide) and of endogenous creatininelike chromogen in dog and man. J. Biol. Chem., 1940, 135, 231.

35. Elkinton, J. R., The volume of distribution of mannitol as a measure of the volume of extracellular fluid, with a study of the mannitol method. J. Clin. Invest., 1947, 26, 1088.

36. Goldring, W., and Chasis, $\mathrm{H}$., Hypertension and $\mathrm{Hy}-$ pertensive Disease. The Commonwealth Fund, New York, 1944.
37. Welt, L. G., and Orloff, J., Effects of infusion of albumin on the excretion of water and electrolytes in normal subjects. J. Clin. Invest., 1949, 28, 818.

38. Relman, A. S., Goodyer, A. V. N., Lawrason, F. D., and Epstein, F. H., Unpublished data.

39. Orloff, J., Welt, L. G., and Stowe, L., The effects of concentrated salt-poor albumin on the metabolism and excretion of water and electrolytes in nephrosis and toxemia of pregnancy. J. Clin. Invest., 1950, 29, 770 .

40. Elkinton, J. R., Crosley, A. P., Jr., Barker, H. G., and Clark, J. K., Alterations in renal hemodynamics and excretion of electrolytes. Federation Proc., 1950, 9, 37.

41. Orloff, J., and Blake, W. D., The effect of concentrated salt-poor human albumin on the excretion of water and electrolytes in normal dogs. J. Clin. Invest., 1950, 29, 837.

42. Landis, E. M., and Hortenstine, J. C., Functional significance of venous blood pressure. Physiol. Rev., 1950, 30, 1.

43. Hooker, D. R., A study of the isolated kidney. The influence of pulse pressure upon renal function. Am. J. Physiol., 1910, 27, 24.

44. Wesson, L. G., Jr., and Anslow, W. P., Jr., Excretion of sodium and water during osmotic diuresis in the dog. Am. J. Physiol., 1948, 153, 465.

45. Selkurt, E. E., and Post, R. S., Renal clearance of sodium in the dog: effect of increasing sodium load on reabsorptive mechanism. Am. J. Physiol., 1950, 162, 639.

46. Dean, R. F. A., and McCance, R. A., The renal responses of infants and adults to the administration of hypertonic solutions of sodium chloride and urea. J. Physiol., 1949, 109, 81.

47. Relman, A. S., Goodyer, A. V. N., and Peterson, E. R., Effect of mannitol on salt excretion during water diuresis. J. Applied Physiol., 1949, 1, 601.

48. Seldin, D. W., and Tarail, R., Effect of hypertonic solutions on metabolism and excretion of electrolytes. Am. J. Physiol., 1949, 159, 160.

49. Goodyer, A. V. N., Relman, A. S., Lawrason, F. D., and Epstein, F. H., Salt retention in cirrhosis of the liver. J. Clin. Invest., 1950, 29, 973.

50. Green, D. M., and Farah, A., Influence of sodium load on sodium excretion. Am. J. Physiol., 1949, 158, 444.

51. Cargill, W. H., Fackler, W. D., McWhorter, R. G., and Warren, J. V., Effect of abdominal compression on chloride excretion following administration of hypertonic saline solution. Am. J. Med., 1949, 7,413 . 